\title{
GÁZTURBINA ÉGÉSTÉR KIALAKÍTÁSOK VIZSGÁLATA PIROLIZÁLT TÜZELŐANYAGHOZ
}

\section{INVESTIAGION OF GAS TURBINE COMBUSTION CHAMBER DESIGN FOR TYRE PYROLYSIS OIL}

\author{
Kondor István Péter ${ }^{1^{*}}$, Kun Krisztián ${ }^{1}$, Zöldy Máté ${ }^{2}$ \\ 1 Jármütechnológia Tanszék, GAMF Müszaki és Informatikai Kar, Neummann János Egyetem, \\ Magyarország \\ ${ }^{2}$ Gépjárműtechnológia Tanszék, Budapesti Müszaki és Gazdaságtudományi Egyetem, Közlekedésmérnöki \\ és Jármümérnöki Kar, Magyarország \\ https://doi.org/10.47833/2020.2.ENG.008
}

\section{Kulcsszavak: \\ Pirolizált olaj \\ Gázturbina \\ Égéstér \\ Befecskendezés}

\section{Keywords:}

Pyrolysis oil

Gas turbine

Combustion chamber

Injection

\section{Cikktörténet:}

Beérkezett 2020. május 15.

Átdolgozva 2020. június 30 .

Elfogadva 2020. július 5.

\begin{abstract}
Összefoglalás
A környezetvédelem, a klímaváltozás mérséklése megköveteli az ipari hulladékok egyre nagyobb mértékü újrahasznositását. $A$ gumihulladékok pirolizációs eljárással történő újrahasznositásával nyert gumialapú pirolizált olaj egy alternativája lehet a gumialapú hulladékok újrahasznosításának. A gázturbinákat a repülöipar mellett széles körben alkalmazzák energiatermelésre, földgáz komprimálására. Mivel e területek kevésbé érzékenyek a tüzelőanyag minőségére jó alternativát kínálnak a gumialapú pirolizált olaj felhasználására. A cikkben egy kísérleti, ellenáramú égéstér konstrukció vizsgálata történik, amelyben különböző nyomású pirolizált olajkeverék kerül befecskendezésre.
\end{abstract}

Abstract
Protecting the environment and mitigating climate change
requires to increase the recycling of industrial waste. Rubber-
based pyrolized oil obtained by recycling the waste rubber by
pyrolysis may be an alternative to the recycling of rubber-based
waste. Gas turbines are widely used for power generation and
compressing natural gas. Because of the fact that, these areas
are less sensitive to fuel quality, they offer a good alternative to
using rubber-based pyrolized oil. This article examines an
experimental, reverse flow combustion chamber design into
which injected by pyrolized oil mixture on different pressures.

\section{Bevezetés}

Az alternatív tüzelöanyagok felhasználása egyre nagyobb méreteket ölt a nyersanyagkészletek csökkenése, valamint a környezetvédelem szempontjából [1]. Számos kutatás és kísérlet foglalkozott már a pirolizációs eljárásokból előállított olajok, úgy mint a vegyes müanyaghulladékból, vagy tisztán gumialapú pirolizált olajok belsőégésü dugattyús motorokban, vagy gázturbinákban történő felhasználásával [2]. Ezeknek az olajoknak a minősége, kémiai fizikai tulajdonságai eltérnek a kereskedelmi forgalomban kapható tüzelőanyagoktól, ezért szükség van a befecskendezés, az égéstér kialakítás, valamint a kipufogógáz összetétel átfogó vizsgálatára, hogy

\footnotetext{
* Kapcsolattartó szerző. Tel.: +36 303781744; fax: +36987 654321

E-mail cím: kondor.peter@gamf.uni-neumann.hu
} 
az elégetésük, és az égés során keletkező károsanyagok határértéken belül maradjanak [3], valamint a gázturbina szerkezeti elemeiben se keletkezzenek rendellenes kopások, meghibásodások.

A folyékony tüzelöanyagok égésének folyamatát gázturbinákban legföképpen a porlasztás, a párolgás, a turbulens keveredés valamint a kémiai reakciók határozzák meg. Ezek a folyamatok egy időben zajlanak le, erős kölcsönhatásban vannak egymással, és nem választhatók szét egykönnyen. A folyékony tüzelőanyagok elő befecskendezése egy lehetőség elválasztani a fizikai és kémiai tulajdonságokat az égéstérben. [4]

A kutatás célja egy mikrogázturbina építése egyedi tervezésű alacsony károsanyag kibocsátású, ellenáramú égéstérrel, amelybe szabályozható injektorral különböző keverési arányban pirolizált olaj kerül bevezetésre.

\section{Ebben a cikkben egy elötervezés zajlik, amely az alábbi fejlesztésekre vonatkozik:}

- Injektor geometria, típus és kivitel kiválasztása

- Gyújtógyertya kiválasztása

- Égéstér felépítésének tervezési fázisa

- Lapátos örvénykeltő kialakítások vizsgálata és tervezése

\section{Ellenáramú égéstér tervezése}

Radiális kompresszor és turbina kialakítások esetén elterjedt megoldás az ellenáramú égéstér (1. ábra) konstrukció, mivel a centrifugálkompresszorból kilépő komprimált közeg tengelyre merőlegesen lép ki, majd az égéstérből kilépve az expandáló gázok a centripetál turbinába szintén tengelyre merőleges irányban lépnek be. Ez a megoldás az axiális gázturbina kialakításokhoz viszonyítva ahol az áramlási irányban elhelyezett gyürüs égéstereket alkalmaznak valamivel nagyobb áramlási ellenállást okoz, de megfelelően megtervezett tüzelőanyag-levegő keveréssel nagyon alacsony károsanyagkibocsátás és gyengébb minőségü tüzelőanyagokkal való üzemeltetés is lehetséges. Ezt a konstrukciót alkalmazzák széles körben villamos áramtermelésre jellemzően $5 \mathrm{MW}$ alatti tartományban olyan területeken, ahol alternatív, vagy gyenge minőségü gáz halmazállapotú tüzelőanyag áll rendelkezésre. [5]

\section{A gázturbina égésérnek a következö folyamatokat kell biztosítania:}

- az égéstérbe lépő levegőnek szétválasztása az égéshez szükséges primér és az égéstermékek lehütésére szolgáló szekunder levegőre

- a levegő és a tüzelöanyag részecskék keverése

- a láng stabilizálása

- az égés befejeztével a szekunder levegővel az égéstermékek lehűtése a turbina előtti gázhőmérsékletre

A fent felsorolt rendkívül bonyolult folyamatokat a kompresszor és a turbina együttmüködési feltételének figyelembevételével kell biztosítani, vagyis az égéstérnek is olyan karakterisztikával kell rendelkeznie, amely megfelel a gázturbina üzemének. [6]

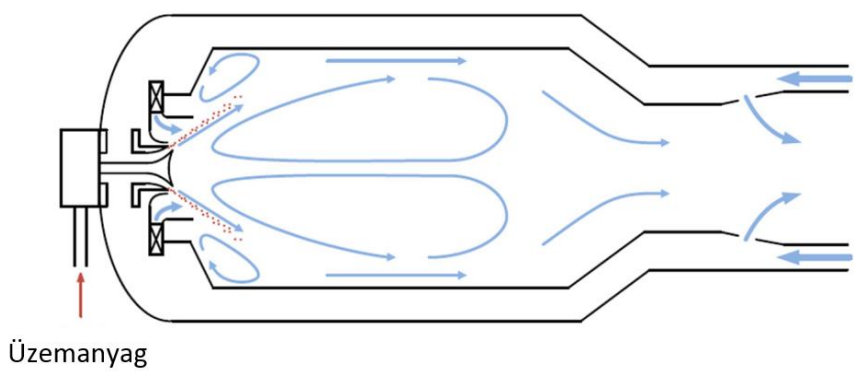

1. ábra. Ellenáramú égéstér elvi vázlata [5] 


\subsection{Lapátos örvénykeltő tervezése pirolizált tüzelőanyaghoz}

Az égéstérben a közeg szétválasztása primér és szekunder tömegáramra az égéstér belépő keresztmetszetének megfelelő kiképzésével valósítható meg. A lángstabilizálást az égéstér első részén az injektor körül koncentrikus csatornába elhelyezett lapátos örvénykeltő biztosítja. $A$ gyulladás feltétele, hogy a tüzelöanyag - levegö részecske már reakcióképes állapotban legyen, tehát a tüzelöanyag - levegö keveredése befejeződjön. A közeg visszaáramoltatásával annyi hőt kell a reakciózóna elejére visszajuttatni, hogy az egyenlő illetve nagyobb legyen, mint a gyújtás energiaszükséglete.[7]

Örvényáramlású égésterek elterjedt konstrukciók a gázturbina iparban mind légnemü mind folyékony halmazállapotú tüzelőanyag alkalmazásánál, mivel az égéstérben keltett örvény hatására stabilabb a lángszerkezet, és gyorsabb a tüzelőanyag levegő keveredése. Az örvénylés intenzitását az égéstér alakja és a lapátos örvénykeltő által képzett örvényszerkezet határozza meg. A folyadékporlasztású égéstér konstrukciókat számos tanulmányban vizsgálták már kísérletekkel, szimulációs módszerekkel. Az eredmények (2. ábra) azt mutatták, hogy a gondosan megtervezett légörvénylésű égéstérben a porlasztás finomabbá válik és gyorsan eloszlik a kamrában, ezáltal az égés minősége nagymértékben javul, ami a káros anyagok kibocsátásának csökkenését eredményezi.[8]

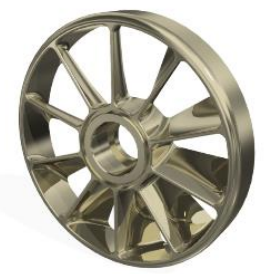

\section{2. ábra. CAD modellben alkotott Lapátos örvénykeltő}

A lapátos örvénykeltő tervezésénél a lángstabilizáció modelljét kellett megvizsgálni (3. ábra). Az ábrából következik, hogy ha a lapátos örvénykeltőn áthaladó levegő forgásirányú összetevője kicsi, akkor a közeg a tüzelőtér falához nem jut el, ezáltal visszaáramlási zóna sem alakul ki, tehát a tüzelőanyag - levegő keverék gyújtása sincs biztosítva.

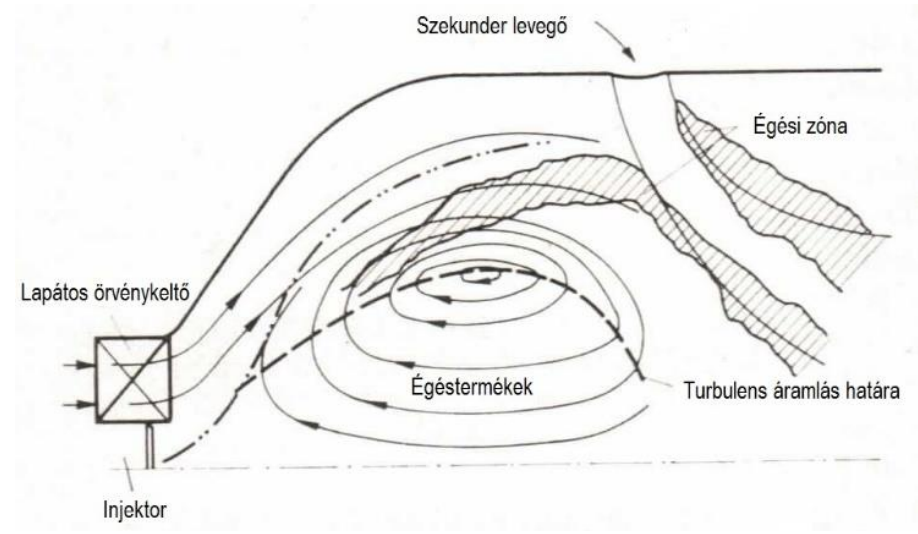

3. ábra. A lángstabilizáció modellje

\section{2. Égéstér tervezése pirolizált tüzelőanyaghoz}

Az égéstér alapvetően két részre osztható primér és szekunder részre, vagy áramlási szempontból primér és szekunder áramra. A két részt a keverési zóna köti össze. A keverési zónában a reakciózónából kilépő égéstermékeket a hideg szekunder árammal kell keverni, hogy biztosítva legyen a turbina előtt szükséges hőmérséklet, amely minden esetben kisebb, mint az égés véghőmérséklete. Ha a meleg és a hideg légáramot egymás melett áramoltatjuk, akkor a keveredés molekuláris diffúzió útján jelentéktelen mértékü. Ugyancsak kihasználatlan a meleg és hideg közeg eltérő sebességủ áramlásakor a két közeg határfelületén keletkező turbulens keveredés, mivel 
ehhez nagyon hosszú úthosszra lenne szükség. Intenzív keveredés csak a hideg és a meleg áram keresztirányú áramoltatásával lehetséges. [9]

A tervezett égéstérnél a szekunder áram a tűzcső keverési zónáján át különböző átmérőjü furatokon keresztül kellett bevezetni az égéstermékhez, hogy a teljes keresztmetszetben a keveredés létrejöjjön (4. ábra).

A keveredési úthosszra és behatolási mélységre használt összefüggés (1 egyenlet):

$$
\left(\frac{l}{D_{1}}\right)^{1,65}=2,91 \frac{\varrho_{1}}{\varrho_{0}} \frac{c_{1}}{c_{0}} \sqrt{\frac{S}{D_{1}}}
$$

A hideg szekunder áram bekeverésénél az égéstermékek lehülnek, az égési reakció megszakad. Az égéstér kilépő keresztmetszetén az egyenletes hőmérséklet elérésére kell törekedni [10]. A reakciózónából kilépő közeg egyenlőtlen hőmérséklet és sebességeloszlása miatt a gondosan megtervezett keveredés ellenére az egyenletes hőeloszlást csak bizonyos eltéréssel lehet tartani. A beporlasztott tüzelőanyag sugár alakja tökéletesen idomul a tüzelőtér keresztmetszetéhez és azt a lehető legegyenletesebben tölti ki [11]. A tűztér ezen szakasza a reakciózóna.

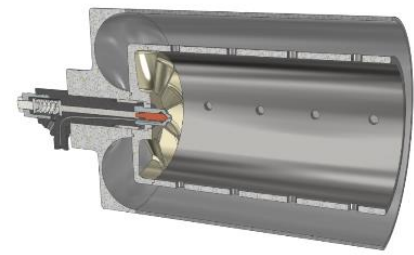

\section{4. ábra. Ellenáramú égéstér CAD modellje}

\subsection{Injektorválasztás pirolizált tüzelöanyaghoz}

Folyékony tüzelőanyagok elporlasztásának célja elérni, hogy a folyadékfázisból gőz halmazállapotba minél hamarabb menjen végbe az átalakulás. Ezt a célt a porlasztási nyomás növelésével lehet elérni. A kutatás célja a gépjármü Common Rail dieselmotorokban alkalmazott nagynyomású injektorral történő befecskendezés vizsgálata gázturbina égéstérben.

A kiválasztott injektor Bosch CR 0445110190 típusú tekercses injektor (5. ábra), amelyet LDx4 típusú Common Rail injektor és szivattyúteszterrel összekötve 10-1350 bar nyomástartományban üzemeltetve lehet a tüzelőanyagot a gázturbina égésterébe porlasztani. Ezt az injektor típust dugattyús diesel motorokban alkalmazzák szakaszos befecskendezésre, de mivel nem piezo kristály vezérlésű lehetőséget nyújt állandó befecskendezésre is.

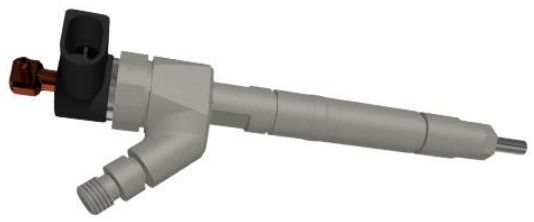

\section{5. ábra. Bosch CR 0445110190 típusú injektor CAD modellje}

\subsection{Gyújtógyertya választás}

A gázturbinákban a gyújtógyertyának csak indítási szakaszban van jelentősége, mikor a tüzelőanyag - levegő keverék égése stabilizálódik a gyújtószikrára már nincs szükség. A kísérleti égéstérhez egy NGK SW12x1,5 menetemelkedésű $26,5 \mathrm{~mm}$ menethosszúságú iridium középelektródás gyújtógyertya lett kiválasztva (6. ábra).

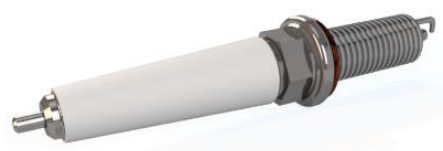

6. ábra. NGK SW gyújtógyertya CAD modellje 


\section{A kialakítás vizsgálata szimulációs környezetben}

\subsection{Rendszeregyenletek}

Tömegmegmaradás egyenlet:

$$
\frac{\partial \rho}{\partial t}+\nabla \cdot(\rho \vec{v})=S_{m}
$$

Lendület megmaradás egyenlet:

$$
\frac{\partial}{\partial \mathrm{t}}(\mathrm{pk})+\frac{\partial}{\partial \mathrm{x}_{\mathrm{i}}}\left(\rho \mathrm{ku} \mathrm{u}_{\mathrm{i}}\right)=\frac{\partial}{\partial \mathrm{x}_{\mathrm{i}}}\left[\left(\mu+\frac{\mu_{\mathrm{i}}}{\sigma_{\mathrm{k}}}\right) \frac{\partial \mathrm{k}}{\partial \mathrm{x}_{\mathrm{i}}}\right]+\mathrm{G}_{\mathrm{k}}+\mathrm{G}_{\mathrm{b}}-\rho \epsilon-\mathrm{Y}_{\mathrm{M}}+\mathrm{S}_{\mathrm{k}}
$$

Energiaegyenlet:

$$
\frac{\partial(\rho E)}{\partial t}+\nabla \cdot[\vec{v}(\rho E+p)]=\nabla \cdot\left[k_{e f f} \nabla \mathrm{T}-\sum_{i} h_{i} \vec{j}_{i}+\tau_{e f f} \cdot \vec{v}\right]+S_{h}
$$

$$
\text { ahol } i=1,2,3 \text {... az együtthatók száma }
$$

Standard $k-\varepsilon$ Model egyenlet:

és

$$
\frac{\partial}{\partial \mathrm{t}}(\mathrm{pk})+\frac{\partial}{\partial \mathrm{x}_{\mathrm{i}}}\left(\rho \mathrm{ku}_{\mathrm{i}}\right)=\frac{\partial}{\partial \mathrm{x}_{\mathrm{i}}}\left[\left(\mu+\frac{\mu_{\mathrm{i}}}{\sigma_{\mathrm{k}}}\right) \frac{\partial \mathrm{k}}{\partial \mathrm{x}_{\mathrm{i}}}\right]+\mathrm{G}_{\mathrm{k}}+\mathrm{G}_{\mathrm{b}}-\rho \epsilon-\mathrm{Y}_{\mathrm{M}}+\mathrm{S}_{\mathrm{k}}
$$

$$
\frac{\partial}{\partial \mathrm{t}}(\rho \epsilon)+\frac{\partial}{\partial \mathrm{x}_{\mathrm{i}}}\left(\rho \epsilon \mathrm{u}_{\mathrm{i}}\right)=\frac{\partial}{\partial \mathrm{x}_{\mathrm{j}}}\left[\left(\mu+\frac{\mu_{\mathrm{t}}}{\sigma_{\epsilon}}\right) \frac{\partial \epsilon}{\partial \mathrm{x}_{\mathrm{j}}}\right]+\mathrm{C}_{1 \epsilon} \frac{\epsilon}{\mathrm{k}}\left(\mathrm{G}_{\mathrm{k}}+\mathrm{C}_{3 \epsilon} \mathrm{G}_{\mathrm{b}}\right)-\mathrm{C}_{2 \epsilon} \rho \frac{\epsilon^{2}}{\mathrm{k}}+\mathrm{S}_{\epsilon}
$$

\section{Peremfeltételek:}

- Megoldás: Nyomás alapú egyensúlyi állapot

- Viszkozitás modell: Sztenderd k-e modell

- Radiációs modell: P1

- Levegő belépési sebesség: $120 \mathrm{~m} / \mathrm{s}(\mathrm{M}=0,35) \mathrm{T}=500 \mathrm{~K}$

- Tüzelőanyag áramlási sebesség $8 \mathrm{~m} / \mathrm{s}$

- Külső légnyomás: sztenderd

- Alkalmazott anyag: $16 \mathrm{MnCr} 5$

- Tüzelőanyag: Gumialapú pirolizált olaj

\subsection{Az égéstér áramlási vizsgálata Ansys szimulációs szoftverben}

A sebességeloszlást az égéstérben a 7 . ábra szemlélteti. Az elsődleges zónában $1000 \mathrm{~m} / \mathrm{s}$ körüli sebesség látható, majd a keveredési zónában lecsökken 500 m/s körüli értékre.

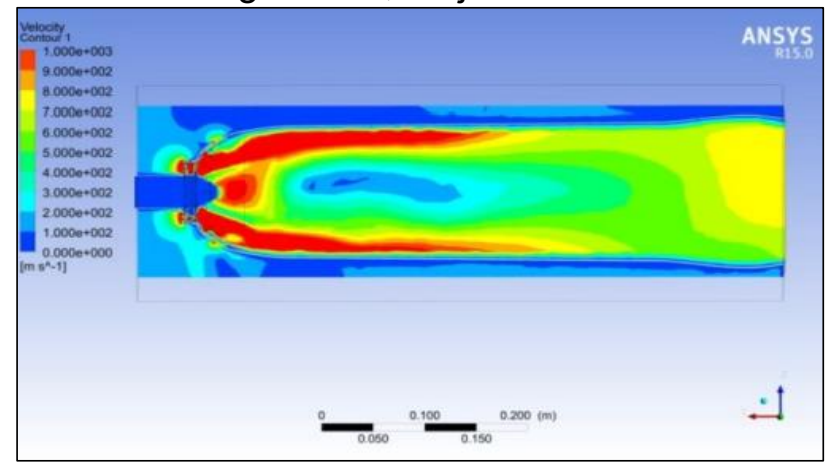

7. ábra Sebességeloszlás

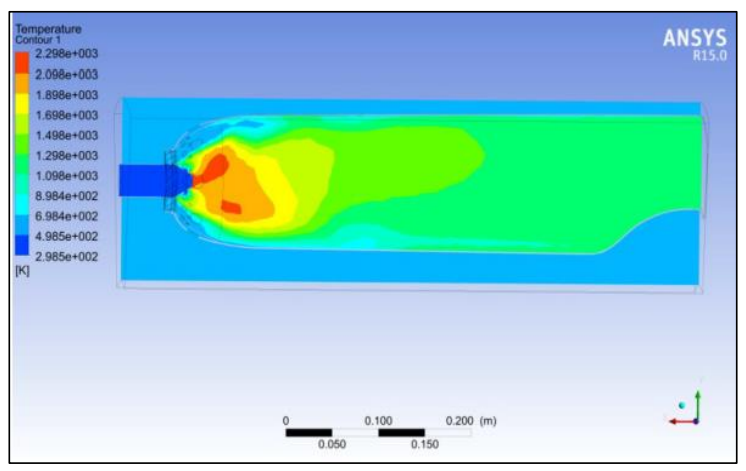

8. ábra Hőmérséklet eloszlás

A hőmérséklet eloszlást a 8. ábra szemlélteti. A láng a másodlagos zónában stabilizálódik, a lángeloszlás nem egyenletes az égéstér mentén. Az elsődleges égési zónában a hőmérséklet $2200 \mathrm{~K}$ majd a szekunder hütésnek köszönhetően a kilépésnél 1230K hőmérsékletre csökken. Az égés a középtengely mentén zajlik a hőközlés felfelé kisebb mértékü, a hőmérséklet a fal közelében $700 \mathrm{~K}$. 


\section{4. Összegzés}

A kutatás célja egy olyan mikrogázturbina égéstér kifejlesztése, amelyben lehetőség van különböző hulladékalapú tüzelőanyagok, föként gumialapú pirolizált olaj vizsgálatára. A vizsgálatok célja a befecskendezési nyomás változtatásának hatása az égési folyamatokra. $A$ vizsgálatok a Kecskeméti Neumann János Egyetem GAMF Karának motorfékpadi laboratóriumában fognak zajlani, ahol lehetőség van a beszívott levegő kondicionálására, hőmérsékleti és nyomásmérésekre, turbina fordulatszám mérésre, kipufogógáz összetétel mérésekre. A mérések kiértékelésével átfogó képet lehet kapni az égés folyamatáról, a károsanyag kibocsátásról, így optimalizálni lehet a rendszer müködését.

A kutatás során sor került az égéstér és a lapátos örvénykeltő megtervezésére, a befecskendező injektor és gyújtógyertya kiválasztására valamint szimulációk lefuttatására. A CAD modell alapján legyártásra fog kerülni az égéstér és a lapátos örvénykeltő.

\section{Irodalomjegyzék}

[1] Tanczos, K., \& Torok, A. (2008). Introducing decisive development orientations into transport modelling. Transport, 23(4), https://doi.org/10.3846/1648-4142.2008.23.330-334

[2] Lukács, Pál: "Fenntartható járműgyártás a 21. században: Elhasznált gépjárművek szerkezeti anyagainak anyagában és energetikailag történő újrahasznosítása”, In: Péter, T (szerk.) Innováció és fenntartható felszíni közlekedés, IFFK 2016, Budapest, Magyarország : Magyar Mérnökakadémia (MMA), 2016

[3] Török, Ádám: "Elhárítási határköltséggörbék alkalmazása a jármügépészeti fejlesztések priorizálásában" In: Csibi, Vencel-József; Barabás, István (szerk.) OGÉT 2018: XXVI. Nemzetközi Gépészeti Konferencia: 26th International Conference on Mechanical Engineering. : OGÉT 2018, Marosvásárhely, Románia : Erdélyi Magyar Müszaki Tudományos Társaság (EMT), (2018) pp. 508-511. , 4 p.

[4] Cristoph M. Arndt, Adam M. Steinberg, Jan Böhnke, Redjem Hadel, Wolfgang Meier German Aerospace Center (DLR), Institute of Combustion Technology, Stuttgart, Germany, University of Toronto, Institute for Aerospace Studies, Toronto Canada „High Speed Imaging of Flame Structure and Dynamic Processes in Swirl Stabilized Prevaporized Liquid Fuel Flames"

[5] Beran M, Koranek M, Axelsson L-U. United States Patent Application for low calorific fuel combustor for gas turbines, no. 12/926,321; 2010.

[6] J.L.H.P. Sallevelt, A.K. Pozarlik, G. Brem University of Twente, Department of Energy Technology, Drienerlolaan 5, 7522 NB Enschede, The Netherlands "Numerical study of pyrolysis oil combustion in an industrial gas turbine"

[7] Lars-Uno Axelsson, Martin Beran and Thijs Bouten OPRA Turbines, the Netherlands "Technical challenges and opportunities for utilizing syngas in gas turbines"

[8] Dr. Fülöp Zoltán "Gázturbinák" Müszaki Könyvkiadó Budapest 1975 ISBN:9631007979

[9] Sara McAllister, Jyh-Yuan Chen A.Carlos Fernandez-Pello "Fundamentals of Combustion Processes" Springer New York 2011. ISBN 978-1-4419-7942-1

[10] Rimkus, Alfredas ; Matijošius, Jonas ; Bogdevičius, Marijonas ; Bereczky, Ákos ; Török, Ádám: "An investigation of the efficiency of using $\mathrm{O} 2$ and $\mathrm{H} 2$ (hydrooxile gas - $\mathrm{HHO}$ ) gas additives in a ci engine operating on diesel fuel and biodiesel, ENERGY 152 pp. 640-651. , 12 p. (2018)

[11] J. Warnatz, U.Maas, R.W.Dibble "Combustion” Springer Berlin 2001. ISBN 978-3-662-04510-7 